International Journal of Current Advanced Research

ISSN: O: 2319-6475, ISSN: P: 2319 - 6505, Impact Factor: SJIF: 5.995

Available Online at www.journalijcar.org

Volume 6; Issue 4; April 2017; Page No. 3545-3554

DOI: http://dx.doi.org/10.24327/ijcar.2017.3554.0312

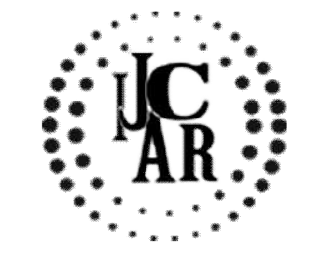

Research Article

\title{
ENERGY, ANERGY AND EXERGY ANALYSIS OF ORGANIC RANKINE CYCLE FOR A RESIDENTIAL APARTMENT USING SOLAR ENERGY BASED ON ASPEN PLUS
}

\section{Adwek Odhiambo George, Imran Ali Shah, Xiang Gou*}

School of Energy and Environmental Engineering, Hebei University of Technology, 5340\# Xiping Road, Shuangkou Town, Beichen District, Tianjin 300401, China

\section{A R T I C L E I N F O}

\section{Article History:}

Received $25^{\text {th }}$ January, 2017

Received in revised form $25^{\text {th }}$ February, 2017

Accepted $22^{\text {nd }}$ March, 2017

Published online $28^{\text {th }}$ April, 2017

\section{Key words:}

Organic Rankine Cycle (ORC); Exergy; Anergy; Solar Thermal Energy; Exergy Destruction

\begin{abstract}
A B S T R A C T
The utilization of solar energy is on a rise due to serious global energy crisis. This paper presents the simulation generated data in energy and exergy analysis to determine the performances for an organic Rankine cycle (ORC). The system was simulated to supply both electrical and thermal energy to an existing residential apartment. The simulation of the operating ORC was performed using Therminol 55 as the heat transmitting fluid within the oil tank, pump and evaporator and using R-245fa as the working fluid within the cycle. The highest power output was obtained when the expander inlet pressure was $2 \mathrm{MPa}$ and the solar source temperature was $163.5^{\circ} \mathrm{C}$, delivering an output power of $33.34 \mathrm{~kW}$ with an achievement of overall process efficiency of $14.55 \%$. The proposed system is intended to be potentially attractive for real estate investors in Thika town with good solar irradiation and without (or with very high cost) access to the general public electricity supply. Detailed analysis of energy and exergy in the organic Rankine cycle has been done in order to determine the best rational use of energy and suggestions on exergy saving are provided based on simulated results.
\end{abstract}

Copyright $(02017$ Adwek Odhiambo George and Imran Ali Shah and Xiang Gou. This is an open access article distributed under the Creative Commons Attribution License, which permits unrestricted use, distribution, and reproduction in any medium, provided the original work is properly cited.

\section{INTRODUCTION}

Global electricity requirement is on the rise and future electricity demand is expected to increase up to $33 \%$ by 2020 and $84 \%$ by $2035[1]$. Following the trend which has been observed in the last 10 years, the cost of electricity is expected to increase gradually. In addition to the environmental challenges, such as global warming, ozone layer depletion and increase in pollution levels, there is a great concern and a heavy influence on worldwide energy policy. Therefore, in order to reduce the environmental impacts and fossils fuels usage, it is necessary to emphasize the use of emerging technology and well-known renewable energy approaches. The organic Rankine cycle (ORC) is a Clausius Rankine cycle which utilizes organic fluid as a working fluid. ORC has the great potential of converting low temperature heat $\left(<300^{\circ} \mathrm{C}\right)$ to electricity [1-2].

The ORCs having heat input and power output with the potential of reversing low grade heat into high grade electricity possess the following merits compared to steam based water Rankine cycle: simple to operate on low temperature heat source; maintenance and operation costs are low; compact; simple start and stop procedure; some models do not require water consumption; quiet during operation;

*Corresponding author: Xiang Gou

School of Energy and Environmental Engineering, Hebei University of Technology, 5340\# Xiping Road,

Shuangkou Town, Beichen District, Tianjin 300401, China requires smaller expanders with higher rotational speeds; the turbine in organic Rankine cycle only requires single stage expanders and the components are commonly available in the market today. The first and second laws of thermodynamics are applied in organic Rankine cycle [2-3]. The thermoeconomics of a Rankine system is strictly linked to the thermodynamic properties of the working fluid used in the system. Many studies of solar ORC power plant exist in the literature, the working fluid selection is the main point in most of the studies and many factors have influenced on it, in medium temperature levels of $150{ }^{0} \mathrm{C}$ to $200{ }^{\circ} \mathrm{C}$. R254ca, $\mathrm{R} 254 \mathrm{fa}$, isobutane and isopentane are usually investigated. Poor selection of a working fluid could result in low efficiency and increase in cost of the ORC plant. Most refrigerants which have lower boiling point than water such as pentane, butane, and hexane can be used in ORC as the working fluids. The working fluids selected are heated with low temperature heat from the collector or recovered waste heat and have properties that differ from those of water in different aspects [3]. Examples of countries where organic Rankine cycles have been installed include: Canada, USA, Germany and Italy though the applications have also been reported in Morocco, Romania, India, Swaziland, Austria, Russia, Finland and Belgium [3].

The following technologies are the main applications used towards harvesting solar energy: 
- Solar photovoltaic (PV) power: A series of photovoltaic panels are used to convert sunlight into electricity through the photo- voltaic effect.

- Solar thermal energy: To collect heat from the sun, solar collector is used. The captured heat will be used directly or stored for providing warm water, space heating and drying purposes depending on the application.

- Solar photovoltaic thermal energy: This is a mix of solar thermal and photovoltaic (PV) components integrated into one system and able to generate electricity and heat simultaneously.

Low efficiency is the main crucial factor that affects the popularity of PV module. Until today, PV modules available commercially in the market from various manufacturers have efficiency ranging from $6 \%$ to $16 \%$, however the claimed efficiency is at a temperature of $25^{\circ} \mathrm{C}$ [4]. In reality, especially for areas with hot weather, their ambient temperature during a sunny day would be more than $35^{\circ} \mathrm{C}$, but the increase in PV temperature leads to the decline in module efficiency [4]. In the near future, the use of solar energy is expected to be crucial and to increase significantly hence there is dire need to improve the performance of thermal power plants integrated with solar thermal energy [5]. Modern steam power plants operating at a steam pressure over $200 \mathrm{bar}$ and at a temperature above $600^{\circ} \mathrm{C}$. As a rule, they produce an electric output power of several units of MWe. Consequently, the suitable sources of heat for such particular power plants are central receiver system and parabolic trough concentrators but dish concentrators can also be used in driving more compact thermal engine with less power output. Derscha et al. [6] carried out a comprehensive research to compare the performance of integrated solar combined cycle systems (ISCCs) with a solar electric generating system (SEGS) and found that integrated solar combined cycle systems are more superior to solar electric generating systems. Analyzing exergy in ORCs system is an approach that explains and calculates the different parts of exergy destruction rate (endogenous/exogenous and unavoidable/avoidable) in each component of an energy system [7, 8, 9]. In other words, in the energy system, energy is always conserved, and exergy shows the quality of energy. Analyzing exergy can be done for both simple and complex organic Rankine cycles by considering each and every component separately, which is a crucial factor in efficiency, improvements and performance evaluation in the organic Rankine cycle with the main aim of overall performance optimization and identification of exergy of destruction sites [10-11]. Christos Trivanidis et al. conducted a research using an organic Rankine cycle coupled with PTC, analyzing it parametrically in order to optimize it financially and energetically using various working fluids [12].

Studies were performed on a hybrid solar gas-turbine plant and identification of the sources of energy losses in their systems [13, 14, 15]. Karellas and Braimakis [16] conducted thermodynamic and economic analyses of a solar biomass system driven tri-generation using vapor compression cycles and ORCs. They recorded thermal efficiency of 5.5\% and the exergy efficiency of $7.6 \%$ in the ORC system. In developing countries, the use of solar energy for electricity generation for small and medium scale using ORC system with liquids as the working fluids is of great importance and is expected to increase in most countries [17, 18]. Currently, commercially there exists in USA one ORC plant of a size $1 \mathrm{MW}$ which was supplied by ORMAT Company; it uses n-pentane as the working fluid with a conversion ratio of solar to electric equal to 0.084 . In 2009 a prototype solar ORC was constructed in Armenia and Spain within the frame of POWERSOL project, and SES36 was used as the working fluid with an output of 5 $\mathrm{kWe}$ and attained an ORC efficiency of 14\% [18-20]. Simulation using a simulation software Aspen plus v8.0 is helpful in designing a solar PVT with optimum and economic conditions to achieve high process efficiency. A comprehensive analysis done on the components conducted taking into account anergy, exergy, or energy analysis of the solar PV thermal plant using ORC in a residential apartment. The aim of this paper is to present a detailed exergy, energy and entropy analysis of ORC for a solar PV thermal plant in a residential apartment with 10 floors and 30 units per floor located in Thika, Nairobi, Kenya, using the geographical conditions of the area and simulated using Aspen plus v8.0. Aspen plus is a computer aided software which uses the under lying physical relationships such as material and energy balances, thermodynamic equilibrium; rate equations etc. to predict process performances e.g., stream properties, operating conditions and equipment sizes etc.

\section{System Description}

\section{Modelling and simulation of the process}

In this study the system is modelled using the process simulator Aspen plus. Solar ORC system is a promising technology to reduce the investments cost at small scale: the system can work at low temperatures and the total installed power can be scaled down to $\mathrm{kW}$ levels. There are three main subsystems in the system simulated ORC, solar plants, and cold-hot water section. The solar collector has the optical part with the energy conversion path in a solar thermal energy system, from solar radiation to thermal. Solar collectors perform the function of adding thermal energy to a liquid medium flowing though the collectors for usage or storage. Solar irradiation is incident to a photovoltaic type solar collector. The ORC is integrated with the solar collector field through the oil tank which contains the heat transmitting fluid. The heat transmitting fluid is heated and pumped from pump P-2 to the oil tank and to the evaporator, and then goes back to the pump. In the evaporator there is heat exchange between the heat transmitting fluid and the working fluid from the pump P-1, the high pressure stream produced in the evaporator is used to run the turbine/expander which is then connected to generator producing electricity. The working principal of the system is presented in Figure 1.

The outlet stream of turbine is cooled in the condenser and converts it to saturated liquid [21, 22]. The solar heated fluid (Therminol 55) from the tank is passed into the plate type heat exchanger (evaporator) and after being cooled down is pumped back to the tank through pump (P-2). The organic working fluid 1,1,1,3,3-pentafluroropropane (R-245fa), vaporizes when passed into the evaporator, which drives the magnetically coupled scroll expander to produce mechanical power.The expander/turbine is connected to generator. After expansion in the process, R-245fa vapor is condensed back into the liquid state, that is, the superheated R-245fa at the 
outlet of the turbine is condensed to saturated liquid in the condenser. The liquid R-245fa is again pressurized by the pump, completing the ORC. Lastly, R-245fa in its liquid form runs into the refrigerant tank to complete its cycle. Mechanical power is produced by the expander in the ORC unit and then coupled to an electrical generator for electricity generation. In some instances, in order to reuse the heat after the expender/turbine, a recuperator may be included in the ORC system to preheat the working fluid (not in this paper scope). A recuperator is essential in improving thermal efficiency of system but at an extra cost, hence an increased power output can be achieved for a decreased heat input in the ORC system. The relatively low efficiency realized with solar $\mathrm{ORC}$ is mainly due to low temperature range obtained from the photovoltaic collectors [4].

\section{Solar Resource}

The present study was carried out using dataset for an average monthly daily information obtained from Kenya meteorological department, Dagoretti station, the meteorological dataset includes Diffuse Horizontal Irradiance (DHI), Global Horizontal Irradiance (GHI), Direct Normal Irradiation (DNI), solar azimuth and elevation, temperature, relative humidity and wind velocity. The simulation was conducted with the aim of creating a platform for real estate investors in residential apartments in Thika located at $\left(0^{0}, 37^{0}\right.$, 41 'E) with an average monthly daily solar insolation ranges from $4.4 \mathrm{kWh} / \mathrm{m}^{2} /$ day to $6.37 \mathrm{kWh} / \mathrm{m}^{2} /$ day and the average monthly temperature ranging from $19.43{ }^{\circ} \mathrm{C}$ to $21.76{ }^{\circ} \mathrm{C}$ as shown in the Figure 2 and 3 respectively. The average sunlight hours in Thika per year is 2600 (of possible 4383 hours) with an average of 8 hours of sunlight per day. The data provided by the meteorological department was used as input to the model, the analysis was done to provide a baseline data for the investors in the area using Aspen plus v8.0. The analysis shows that Thika has reliable energy resources with little variability and the transparency of the sky is also encouraging as it shows that there is little obstruction to the solar radiation.

\section{$P V$ system in ORC}

PV technology with a secondary thermal system that operates on a waste heat is used in this simulation, commonly referred to as PVT system. Thermodynamics analysis using the software generated data has been carried out on the system between the temperature range $80{ }^{\circ} \mathrm{C}$ to $180{ }^{\circ} \mathrm{C}$ proving the applicability of the system in Thika and its effectiveness, using therminol oil as the heat transmitting fluid (HTF) in the oil tank (o-tank) direct energy storage TES system and an ORC power plant. HTF storage tank (o-tank) is installed in order to attenuate the fluctuation of solar irradiation during the day and maintain stable operation of ORC engine (see Figure 1)

The HTF temperature required by ORC system in consideration, makes therminol oil the most suitable option for temperature levels $80{ }^{0} \mathrm{C}-180{ }^{0} \mathrm{C}$. The $\mathrm{PV}$ section includes the photovoltaic arrays comprising of several sub arrays, the total modules area is better calculated in the following section.

The correlations expressing PV cell temperature $\left(\mathrm{T}_{\mathrm{c}}\right)$ as a function of weather variables in Thika such as ambient temperature $\left(\mathrm{T}_{\mathrm{amb}}\right)$, area wind speed $\left(\mathrm{V}_{\mathrm{w}}\right)$, solar radiation, material and system dependent properties such as glazing cover, transmittance etc. The effect of temperature on the electrical efficiency of a PV cell was calculated using the equation

$P_{\text {max }}=I_{\text {max }} V_{\text {max }}=(F F) I_{S C} V_{O C}$

Both open circuit voltage $\left(\mathrm{V}_{\mathrm{OC}}\right)$ and fill factor $(\mathrm{FF})$ decreases substantially with temperature because the thermally excited electrons start to dominate the electrical properties of the semiconductor, while the short circuit current increases slightly, leading to a linear equation in the form:

$\eta_{c}=\eta_{T \text { ref }}\left[1-\beta_{\text {ref }}\left(T_{C}-T_{\text {ref }}\right)+\gamma \log _{10} I\right.$
$\eta_{c}=\eta_{\text {Tref }}\left[1-\beta_{\text {ref }}\left(T_{C}-25\right)+\gamma \log _{10} 1000\right.$

Given that $\beta_{\text {ref }}=0.0045 K^{-1}, \gamma=0.12$ for crystalline silicon module in the PVT system and $I=1000 \mathrm{~W} / \mathrm{m}^{2}$.

$\beta_{\text {ref }}$ depends on the PV material and reference temperature, it's given by;

$\beta_{\text {ref }}=\frac{1}{T_{x}-T_{\text {ref }}}$

Where $T_{x}$ is the high temperature at which PV module electrical efficiency drops to Zero, for crystalline silicon solar cell $T_{x}=270^{\circ} \mathrm{C}$

Based on the average monthly daily information for Thika town, the monthly average efficiency can be determined from the following equation;

$\bar{\eta}=\eta_{T r e f}\left[1-\beta_{\text {ref }}\left(\overline{T_{c}}-\overline{T_{\text {ref }}}\right)-\beta_{\text {ref }} \overline{\frac{(\tau \alpha)}{\eta U_{L}}} \overline{V H_{T}}\right]$

The over bar denotes the monthly average quantities, $\mathrm{n}$ is the number of hours per day, $U_{L}$-the overall thermal loss coefficient, $H_{T}$ is the monthly average insolation on the plane of the array, $\mathrm{V}$ is the dimensionless function of such quantities, as the monthly average clearness index and the ratio of monthly total radiation on the array to the horizontal surface (see Figure 2 and 3).

\section{Solar thermal cycle}

Diffuse radiation or scattered radiation and direct radiation or beam radiation which is the radiation that arrives on the ground without being scattered by the clouds are the two main components of solar radiation. Global radiation is the total radiation received which is the sum of scattered radiation and direct radiation. There are two main types of (water/air) PV/T solar collectors available in the market today namely: nonconcentrated solar collectors and concentrated solar collectors. The solar energy is collected using photovoltaic solar collector operating at a temperature ranging from $80^{\circ} \mathrm{C}$ $180^{\circ} \mathrm{C}$. To calculate the absorber surface temperature for the collector, $T_{\mathrm{ab}}$, the following formula was applied [27].

$T_{a b}^{4}=(1-\eta) \frac{A_{a p} s}{A_{a b} \sigma}$,

Where $A_{a p}, s, \sigma, A_{a b}, \eta$ are aperture area, solar flux, Stefan Boltzmann constant, absorber area and collector efficiency respectively.

The photovoltaic collector efficiency can be calculated with the following relation:

$\eta_{c o l}=\frac{i x v}{I_{t, a} A_{a p}}=\left(\frac{\eta_{G}}{\eta_{s t d}}\right)\left(\frac{\eta_{G, T}}{\eta_{G}}\right)\left(\frac{\eta_{G, E(\gamma)}}{\eta_{s t d}}\right)$, 
where $i$ is the electrical current through the cell; $v$ represents the voltage across the cell; $I_{t, a}$ stands for the global irradiance of the solar aperture; and $\frac{\eta_{G}}{\eta_{s t d}}, \frac{\eta_{G, T}}{\eta_{G}}, \frac{\eta_{G, E(\gamma)}}{\eta_{s t d}}$ are the ratios of efficiency of the panel at specified irradiance level to efficiency at standard irradiance, efficiency of the panel at specified cell temperature to its efficiency at specified irradiance level, and efficiency of panel at specified air mass to its efficiency at specified irradiance level respectively.

The solar flux was taken to be $1000 \mathrm{~W} / \mathrm{m}^{2}$ [26]. Diffuse radiation is calculated using correlations from Orgill and Hollands [28];

$\frac{I_{d}}{I}=\left\{\begin{array}{c}1.0+0.24 k_{T} \\ 1.557-1.84 k_{T} \\ 0.177 k_{T}\end{array}\right\} \begin{gathered}k_{T}<0.35 \\ 0.35<k_{T}<0.75, \\ k_{T}>0.75\end{gathered}$

where clear sky index $k_{T}=\frac{I}{I_{0}}$ where $I$ and $I_{0}$ are measured global radiation and the calculated global radiation which depends on latitude, solar time for the Thika area and day of the year. Francis Oloo et al. [31] reported annual mean radiation of $6.5 \mathrm{kWh} / \mathrm{m}^{2}$ in Thika town (data available at http://swera.unep.net) and a daily defuse radiation in central Kenya is $5.0 \mathrm{MJ} / \mathrm{m}^{2} /$ day with a clearness index of the range 0.4 and 0.7 . To obtain the direct radiation, the diffuse radiation was subtracted from value for the global radiation and the required power output and hot water supply was achieved from total panel area of $950 \mathrm{~m}^{2}$, the reflectivity of the aperture surface was taken as 0.96 .

\section{Working Fluid Selection}

Substances which are most commonly considered as the working fluids of the low-temperature solar ORC are shown in Table 1.

Table 1 Thermophysical properties of the selected pure working fluids [1]

\begin{tabular}{ccccc}
\hline Fluid & $\mathbf{M}(\mathbf{g} / \mathbf{m o l})$ & $\mathbf{T}_{\text {crit }}\left({ }^{\circ} \mathbf{C}\right)$ & $\mathbf{P}_{\text {crit }}(\mathbf{b a r})$ & $\mathbf{T}_{\text {boiling }}\left({ }^{\circ} \mathbf{C}\right)$ \\
\hline Cyclohexane & 84.2 & 280.5 & 40.8 & 80.3 \\
Hexane & 86.2 & 234.7 & 30.3 & 68.3 \\
Isobutane & 58.1 & 134.7 & 36.3 & -12.1 \\
Isohexane & 86.2 & 224.6 & 30.4 & 59.8 \\
Isopentane & 72.1 & 187.2 & 33.8 & 27.4 \\
Pentane & 72.1 & 196.6 & 33.7 & 35.7 \\
R245fa & 134 & 154 & 36.5 & 14.8 \\
R365mfc & 148.1 & 186.9 & 32.7 & 39.8 \\
Ammonia & 17.0 & 405.8 & 112.8 & -33.3 \\
\hline
\end{tabular}

The following condition is considered in selecting $\mathrm{R}-245 \mathrm{fa}$ as the suitable working fluid, the critical temperature of the working fluid and the critical pressure was examined. Table 1, shows various properties for the various working fluids as compared to R-245fa. The thermodynamic properties like enthalpy, entropy, flow rates at various nodes have been generated by the model which are used in the calculation of performance parameters like components effectiveness/ efficiency.

Apart from the organic substances, $\mathrm{NH}_{3}$ has also been considered mainly due to its good characteristics like fluid flow properties. These working fluids have been analyzed in some low-temperature solar ORC investigations in various research papers.

However, compared to other organic fluids, ammonia has been found to be having saturation pressure which is considerably higher than many other organic fluids and its high toxicity. Most fluids shown in Table 1 are ozone friendly substances with few of them having low global warming potential.Taking ambient temperature and pressure values of $25^{\circ} \mathrm{C}$ and $101.325 \mathrm{kPa}$ respectively $[2,5,29,30]$.

In this simulation, Therminol 55 was used as HTF and 1,1,1,3,3-pentafluroropropane (R254fa) was used as the working fluid in the ORC system. The 1,1,1,3,3pentafluoropropane (R-245fa) was offering the best overall efficiency as the working fluid despite the solar plant exhibiting lowest efficiency. An isomer of 1,1,1,3,3pentafluroropropane (R-245fa), is used by UTC technologies in their commercialized ORC system [33] taking into consideration the global environmental impact, toxicity and flammability of the working fluid.

The choice of 1,1,1,3,3-pentafluroropropane (R-245fa) as the working fluid was based on the thermodynamic investigation, considering all the assumptions in Table 2, the operational condition of R245fa was determined as follows:

Table 2 Operation assumptions

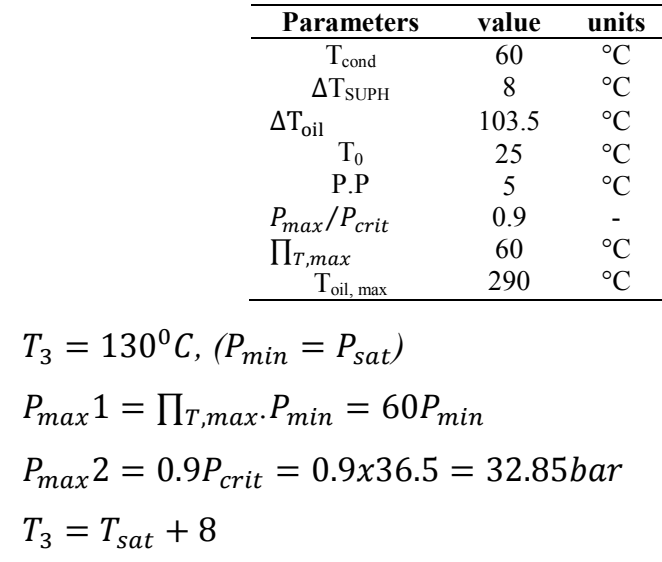

At isentropic point;

$h_{4}=h\left(p=p_{\text {min }}, s=s_{3}\right)$

$h_{4}=\mathrm{h}_{3}-\eta_{i s, T}\left(h_{3}-\mathrm{h}_{4}\right)$

$T_{1}=T_{C}=30^{\circ} \mathrm{C}$, when $h_{1}=h, T=T_{1}, s_{1}=S$

Therefore $h_{2, \text { isen }}=h\left(p-p_{\max }\right)$

$h_{2}=h_{1}+w_{\text {pump }}=h_{1}+\frac{h_{2, \text { isen }}-h_{1}}{\eta_{\text {isen,pump }}}$

$P_{e}=m_{O R C} \cdot \eta_{G e n} \cdot\left(h_{3}-h_{4}\right)-\frac{m_{\text {ORC }} \cdot w_{\text {pump }}}{\eta_{\text {motor }}}$

Given that $P_{e}=33.34 k W$

$Q_{n e t}=m_{\text {ORC }}\left(h_{3}-h_{2}\right)=m_{\text {oil }} \cdot \mathrm{cp}_{\text {oil }} \cdot \Delta T_{\text {oil }}$

$\eta_{O R C}=\frac{P_{e}}{m_{O R C}\left(h_{3}-h_{2 \mathrm{~A}}\right)}=\frac{333 \mathrm{~kW}}{Q_{n e t}}$

Energy balance in the evaporator

$$
\begin{aligned}
& \mathrm{m}_{\text {oil }}=\frac{Q_{\text {net }}}{\mathrm{cp}_{\text {oil }} \cdot \Delta T_{\text {oil }}}=\frac{333 \mathrm{~kW}}{79 c p_{\text {oil }} \cdot \eta_{\text {ORC }}} \\
& T_{\text {oil }, \text { in }}=T_{\text {sat }}+P P+\frac{m_{O R C} \cdot\left(h_{3-} h\left(p=p_{\text {max }}\right)\right)}{m_{\text {oil }} \cdot \mathrm{cp} \text { oil }}=T_{\text {sat }}+5+ \\
& 79 \frac{\eta_{\text {ORC }} \cdot\left(h_{3}-h\left(p=p_{\text {max }}\right)\right)}{\left(h_{3}-h_{4}\right)-\frac{w_{\text {pump }}}{\eta_{\text {motor }}}}
\end{aligned}
$$


The following screening properties were also taken into consideration: low ozone depletion potential (ODP), availability in the market, economical, higher efficiencies when used as a working fluid, low specific volumes, moderate pressures in the heat exchangers within the ORC system, low global warming potential (GWP), long service life, and super pump ability at low temperature among other properties.

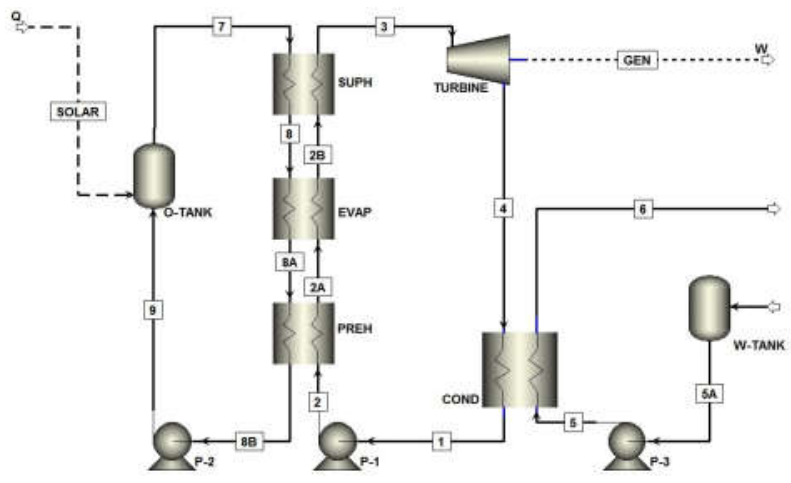

Figure 1 Schematic diagram of the organic Rankine cycle driven by solar energy

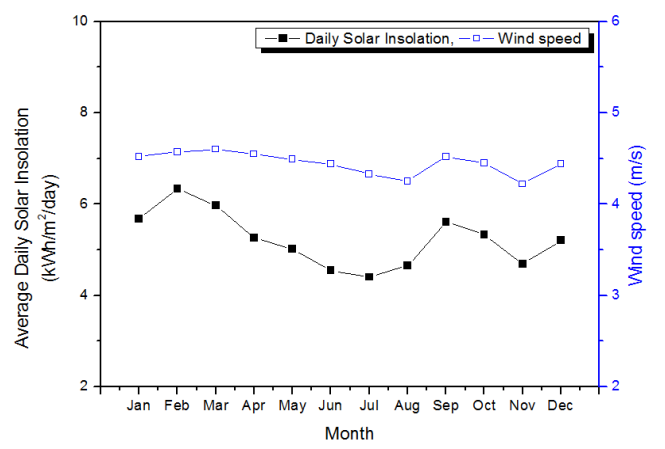

Figure 2 The average Monthly daily solar insolation and wind speed for Thika

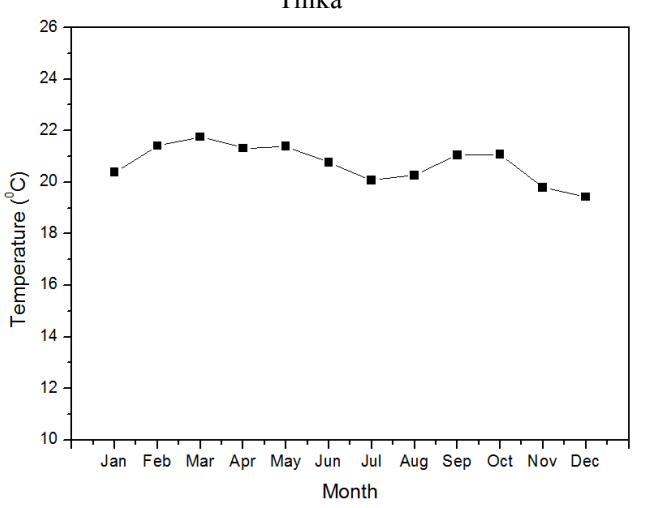

Figure 3 The average Monthly daily temperature for Thika

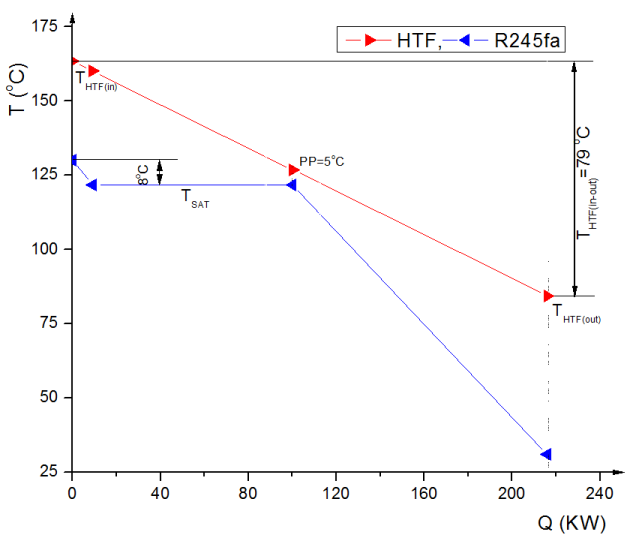

Figure 4 T-Q heat exchange between Heat Transmitting fluid (HTF) and working fluid
Therminol 55 used in this simulation as HTF is a synthetic hydrogen-carbon mixture with a noncorrosive nature to the metals used in heat transfer. It has kinetic viscosity of $19 \mathrm{~mm}^{2} / \mathrm{s}$ at $40^{\circ} \mathrm{C}$, average molecular weight of $320 \mathrm{~g} / \mathrm{mol}$ and a critical pressure of 13.2 bar.

Various usual and realistic assumptions have been put into consideration. In order to simulate this system using Aspen plus v8.0 in a dynamic basis. First of all, the system nominal electricity power is selected to be $33.34 \mathrm{~kW}$ el for all the examined cases. The maximum temperature of the heat transfer fluid in the inlet of the evaporator was set to be $31^{\circ} \mathrm{C}$, because this study aims to this temperature region. The HTF transfers its heat to the ORC system and its temperature is reduced by $79{ }^{0} \mathrm{C}$. The pinch point in the evaporator was selected to be at $50{ }^{\circ} \mathrm{C}$, according to T-Q diagram in Figure 4.

\section{Load Estimation}

In the present study a building apartment located in Thika is considered, and it is a 10 floor building with a total covered area of $33000 \mathrm{~m}^{2}$ (3300 $\mathrm{m}^{2}$ per floor) comprising of total 300 units (30 units each floor). The apartment includes corridor with the total covered area of $3000 \mathrm{~m}^{2}$ (i.e. $300 \mathrm{~m}^{2}$ per floor); dimension of corridor is $150 \mathrm{~m}(\mathrm{~L}) \times 2 \mathrm{~m}(\mathrm{~W})$, and that of one unit is $10 \mathrm{~m}(\mathrm{~L}) \times 10 \mathrm{~m}(\mathrm{~W})$ which is calculated to be a living area of $100 \mathrm{~m}^{2}$ per unit. The roof to ceiling height is at $4 \mathrm{~m}$. The average occupant per unit in the apartment is 5 people, total number of occupants is 1500 (i.e. 30 units $\times 10$ floors $\times$ 5 persons). The required heating and power loads of this house are supposed to be provided by the proposed ORC cycle. To determine the heating and cooling loads requirements, the following assumptions were considered: wall insulation thickness is taken to be 1 inch; every window has internal shading; glasses are single pane; the building orientation is towards the west; and the roof is flat air vented with 1 -inch insulation. In estimation of the electrical power required in the above mentioned residential apartment, the following appliances with the average power required for each one is assumed.

Table 3 Input values to the system

\begin{tabular}{ccc}
\hline Parameters & Value & Units \\
\hline Solar collector temperature $\mathrm{t}_{7}$ & 163.5 & ${ }^{\circ} \mathrm{C}$ \\
Isentropic efficiency for the turbine & 80 & $\%$ \\
pump isentropic efficiency & 75 & $\%$ \\
Electrical generator efficiency & 95 & $\%$ \\
Ambient temperature $\mathrm{T}_{0}$ & 25 & ${ }^{\circ} \mathrm{C}$ \\
Pinch point temperature of the evaporator \& condenser & 5 & ${ }^{\circ} \mathrm{C}$ \\
\hline
\end{tabular}

Table 4 Result analysis simulated at different evaporator exit temperatures

\begin{tabular}{|c|c|c|c|c|c|c|}
\hline \multirow{2}{*}{ Stream Parameters } & \multicolumn{2}{|c|}{$129^{\circ} \mathrm{C}$} & \multicolumn{2}{|c|}{$130{ }^{\circ} \mathrm{C}$} & \multicolumn{2}{|c|}{$131^{\circ} \mathrm{C}$} \\
\hline & $\mathrm{T}\left({ }^{\circ} \mathrm{C}\right) \mathrm{I}$ & $\mathbf{P}$ (MPa) & $\mathbf{T}\left({ }^{\circ} \mathrm{C}\right)$ & P (MPa) & $\mathbf{T}\left({ }^{\circ} \mathrm{C}\right)$ & (MPa) \\
\hline $\begin{array}{l}\text { ORC Working Fluid at } \\
\text { Point } 1\end{array}$ & 30 & 0.17 & 30 & 0.18 & 30 & 0.18 \\
\hline $\begin{array}{l}\text { ORC Working Fluid at } \\
\text { Point } 2\end{array}$ & 31.06 & 2 & 31.06 & 2 & 31.06 & 2 \\
\hline $\begin{array}{l}\text { ORC Working Fluid at } \\
\text { Point } 3\end{array}$ & 129 & 2 & 130 & 2 & 131 & 2 \\
\hline $\begin{array}{c}\text { ORC Working Fluid at } \\
\text { Point } 4\end{array}$ & 60 & 0.12 & 60 & 0.12 & 60.02 & 0.1 \\
\hline Water (Inlet) & 15 & 0.5 & 15 & 0.5 & 15 & 0.5 \\
\hline Water (Outlet) & 54.87 & 0.5 & 54.89 & 0.5 & 53.33 & 0.5 \\
\hline $\begin{array}{l}\text { Heat Transmitting Oil } \\
\text { (Inlet) }\end{array}$ & 163 & 0.35 & 163.5 & 0.35 & 164.5 & 0.35 \\
\hline $\begin{array}{c}\text { Heat Transmitting Oil } \\
\text { (Outlet) }\end{array}$ & 84.5 & 0.35 & 84.5 & 0.35 & 84.5 & 0.35 \\
\hline
\end{tabular}


Light (300 W), TV-LCD (158 W), washing machine (345 W), refrigerator $(140 \mathrm{~W})$, fan coil $(140 \mathrm{~W})$, computer $(150 \mathrm{~W})$, the total power consumption is taken to be $1.3 \mathrm{~kW}$ per house per day. To estimate the required load for domestic hot water supply, the maximum consumption is considered for each unit. Based on the calculations, the system is supposed to provide warm water at a rate of $3600 \mathrm{~kg} / \mathrm{h}$, and a temperature of $55{ }^{\circ} \mathrm{C}(\bar{\mp} 0.5)$ to cater for the residents water consumption requirements. Given that each person consumes approximately 55 - 60 litres/day (shower/ bathing/ washing etc.), the total water consumption is 3600 litres per hour.

\section{Energy, Anergy and Exergy analysis}

Energy is neither destroyed nor created according to the first law of thermodynamics, hence energy is conserved. The first law of thermodynamics highlights on quantity of energy and fails to account for the quality of energy in the system. The following mass and energy balance equations are applied to investigate the heat transfer and work for a steady state condition with an assumption that $\Delta K \boldsymbol{E}=\mathbf{0}$ and $\Delta \mathbf{P E}=\mathbf{0}$ $[21,23,24]$. Two major assumptions that are taken into consideration: 1) a steady state conditions are reached by the system, and 2) heat losses to the environment and the drop in pressure in the pipeline are neglected.

Table 5 Results for $\mathrm{T}=130{ }^{\circ} \mathrm{C}$

\begin{tabular}{|c|c|c|}
\hline Parameters & Units & Value \\
\hline W Turbine & $\mathrm{kJ} / \mathrm{hr}$ & $1.33 \times 10^{5}$ \\
\hline Q Condenser & kJ.hr & $6.49 \times 10^{5}$ \\
\hline W pump & $\mathrm{kJ} / \mathrm{hr}$ & $5.49 \times 10^{3}$ \\
\hline Q Evaporator & $\mathrm{kJ} / \mathrm{hr}$ & $7.77 \times 10^{5}$ \\
\hline mORC & $\mathrm{kg} / \mathrm{hr}$ & $3.00 \times 10^{3}$ \\
\hline$\eta_{O R C}$ & $\%$ & 14.55 \\
\hline $\mathrm{T}_{4}$ & ${ }^{\circ} \mathrm{C}$ & 60 \\
\hline $\mathrm{T}_{7}$ & ${ }^{\circ} \mathrm{C}$ & 163.5 \\
\hline Enthalpy at point 1 & $\mathrm{~kJ} / \mathrm{kg}$ & 4569 \\
\hline Enthalpy at point 3 & $\mathrm{~kJ} / \mathrm{kg}$ & 4310 \\
\hline Enthalpy at point 4 & $\mathrm{~kJ} / \mathrm{kg}$ & 4351 \\
\hline Enthalpy at point 5 & $\mathrm{~kJ} / \mathrm{kg}$ & 16000 \\
\hline Enthalpy at point 7 & $\mathrm{~kJ} / \mathrm{kg}$ & 9280 \\
\hline
\end{tabular}

Table 6 Exergy \& anergy result analysis

\begin{tabular}{ccccc}
\hline Parameter $\left(\mathbf{x 1 0}^{3}\right)$ & Evaporator & Turbine & Condenser & Pump \\
\hline $\mathrm{Ex}^{\mathrm{F}}[\mathrm{kJ} / \mathrm{hr}]$ & 777.27 & 154.30 & 189.45 & 5.49 \\
$\mathrm{Ex}^{\mathrm{P}}[\mathrm{kJ} / \mathrm{hr}]$ & 151.21 & 133.30 & 9.62 & 4.20 \\
$\mathrm{I}[\mathrm{kJ} / \mathrm{hr}]$ & 626.07 & 21.00 & 179.83 & 1.29 \\
\hline
\end{tabular}

Equations used to perform the analysis for a basic ORC in Figure 1 are:

$\sum \dot{m}_{i}-\sum \dot{m}_{o}=0$,

$\dot{Q}+\sum \dot{m}_{i} h_{i}=\dot{W}+\sum \dot{m}_{0} h_{0}$,

where $\dot{W}, \dot{m}, h, \dot{Q}$, 'i', 'o' are work rate, rate of mass flow, specific enthalpy, heat transfer rate, subscript for inlets, and subscript for outlets, respectively.

\section{Energy Analysis}

Turbine

$\dot{W}_{\mathrm{T}}=\dot{m}_{\text {ORC }}\left(h_{3, \text { ORC }}-h_{4, O R C}\right)$

Condenser

$\dot{Q}_{C O N D}=\dot{m}_{O R C}\left(h_{4, O R C}-h_{1, O R C}\right)$

Pump

$\dot{W}_{\mathrm{p}}=\dot{m}_{\text {ORC }}\left(h_{2, O R C}-h_{1, O R C}\right)$

Preheater, Evaporator \& Superheater

$\dot{Q}_{\text {Total }}=\dot{m}_{\text {ORC }}\left(h_{3, O R C}-h_{2, O R C}\right)$
$\dot{m}_{O R C}\left(h_{3, O R C}-h_{2 A, O R C}\right)=\dot{m}_{o i l}\left(h_{7}-h_{8 A}\right)$

$\dot{m}_{O R C}=\frac{\dot{m}_{\text {oil }}\left(h_{7}-h_{8 A}\right)}{\left(h_{3, O R C}-h_{2 A, O R C}\right)}$

$T_{2 A}=T_{8 A}-T_{P P}$

$T_{P P}$ is the pinch point which is fixed at $5{ }^{0} \mathrm{C}$,

Net power

$\dot{W}_{O R C}=\dot{W}_{T}-\dot{W}_{P}=\dot{W}_{3,4}-\dot{W}_{1,2}=\dot{Q}_{E V A P}-\dot{Q}_{C O N D}$

$\dot{W}_{O R C}=\dot{Q}_{2,2 A}+\dot{Q}_{2 A, 2 B}+\dot{Q}_{2 B, 3}-\dot{Q}_{C O N D}$

Where $\dot{Q}_{2,2 A}, \dot{Q}_{2 A, 2 B}, \dot{Q}_{2 B, 3}$ represent the preheating, evaporating and superheating sections, and

$T_{2 A}=T_{2 B}=T_{E V A P}$

Thermal Efficiency

$\eta_{O R C}=\frac{W_{T}-W_{P}}{Q_{E V A P}}$

From the equation below, Exergy is a thermodynamic property which is dependent on the system surrounding environment (reference environment) in an extent that no changes in its intensive properties such as pressure $\left(\mathrm{P}_{0}\right)$, and temperature $\left(\mathrm{T}_{0}\right)$ of the system under analysis are observed. Hence the maximum theoretical work attainable from the interaction of a system with its surrounding environment up to when equilibrium state between them is reached and can also be seen as the departure state of a system from the reference environment. Its analysis makes use of both the first and the second law of thermodynamics which assists in overcoming of the various shortcomings of energy analysis.It is important in identifying the process inefficiencies magnitude, causes and locations of inefficiencies [32]. The specific exergy, energy and anergy for a flow stream disregarding potential and kinetic energies are given as:

$$
\begin{aligned}
& \text { Exergy }=\left(h-h_{0}\right)-T_{0}\left(s-s_{0}\right) \\
& \text { Energy }=\left(h-h_{0}\right) \\
& \text { Anergy }=T_{0}\left(s-s_{0}\right)
\end{aligned}
$$

The anergy $T_{0}\left(s-s_{0}\right)$, which is also known as the exergy destruction, and exergy efficiency for all components in the ORC system will be now defined below based on Figure 1. The anergy can be calculated as indicated in the equation below;

$\dot{E}=T_{0} S_{g e n}$

where $T_{0}$ is the dead state temperature, and $S_{g e n}$ is the rate of entropy generation.

The system components exergy analysis is as follows [26].

Condenser

$$
\begin{gathered}
\dot{E} x_{\text {Cond }}^{P}=Q_{\text {Cond }}^{\cdot}\left(1-\frac{T_{0}}{T_{m W}}\right) \\
T_{m W}=\frac{h_{4, \text { ORC }}-h_{1, \text { ORC }}}{S_{4, \text { ORC }}-S_{1, \text { ORC }}} \\
\dot{E} x_{\text {Cond }}^{F}=\dot{m}_{\text {ORC }}\left(h_{1, O R C}-h_{4, O R C}-T_{0}\left(S_{1, O R C}-S_{4, O R C}\right)\right)( \\
\dot{I}_{\text {Cond }}=\dot{m}_{\text {ORC }}\left(E x_{1, O R C}-E x_{4, O R C}\right)-Q_{\text {Cond }}\left(1-\frac{T_{0}}{T_{m W}}\right)
\end{gathered}
$$




$$
\begin{gathered}
\dot{E} x_{T}^{P}=\dot{W}_{T} \\
\dot{E} x_{T}^{F}=\dot{m}_{O R C}\left(h_{4, O R C}-h_{3, \text { ORC }}-T_{0}\left(S_{4, \text { ORC }}-S_{3, \text { ORC }}\right)\right) \\
\dot{I}_{T}=\dot{m}_{O R C} \cdot T_{0}\left(S_{4, \text { ORC }}-S_{3, \text { ORC }}\right)
\end{gathered}
$$

Pump

$$
\begin{gathered}
\dot{E} x_{\text {Pump }}^{p}=\dot{m}_{\text {ORC }}\left(h_{2, \text { ORC }}-h_{1, \text { ORC }}\right. \\
\left.-T_{0}\left(S_{2, \text { ORC }}-S_{1, \text { ORC }}\right)\right) \\
\dot{E} x_{\text {Pump }}^{F}=\dot{W}_{P} \\
\dot{I}_{\text {Pump }}=\dot{m}_{\text {ORC }} \cdot T_{0}\left(S_{2, \text { ORC }}-S_{1, \text { ORC }}\right)
\end{gathered}
$$

Preheater, Evaporator \& Superheater

$$
\begin{aligned}
& \dot{E} x^{p}=\dot{E} x_{P R E H}+\dot{E} x_{E V A P}+\dot{E} x_{S U P H} \\
& \dot{E} x^{F}=\left(\dot{E} x_{P R E H}+\dot{E} x_{E V A P}+\dot{E} x_{S U P H}\right)\left(1-\frac{T_{0}}{T_{m H}}\right)
\end{aligned}
$$

Where $T_{m H}=\frac{T_{7, \text { oil }}-T_{8 B, o i l}}{\operatorname{In}\left(\frac{T_{7, \text { oil }}}{T_{8 B, o i l}}\right)}$

$\dot{E} x_{P R E H}=\dot{m}_{O R C}\left(h_{2, O R C}-h_{2 A, O R C}-T_{0}\left(S_{2, O R C}-S_{2 A, O R C}\right)\right)$

$\dot{E} x_{E V A P}=\dot{m}_{O R C}\left(h_{2 B, O R C}-h_{2 A, O R C}-T_{0}\left(S_{2 B, O R C}-\right.\right.$ $\left.\left.S_{2 A, O R C}\right)\right)$

$\dot{E} x_{S U P H}=\dot{m}_{O R C}\left(h_{3, O R C}-h_{2 B, O R C}-T_{0}\left(S_{3, O R C}-S_{2 B, O R C}\right)\right)$

$\dot{E} x^{p}=\dot{m}_{O R C}\left(h_{3, O R C}-h_{2, O R C}-T_{0}\left(S_{3, O R C}-S_{2, O R C}\right)\right)$

$\dot{I}=\dot{Q}\left(1-\frac{T_{0}}{T_{m H}}\right)-\dot{m}_{O R C}\left(\dot{E} x_{3, O R C}-\dot{E} x_{2, O R C}\right)$

where $\dot{I}_{\text {Cond }}, \dot{I}_{T}$ and $\dot{I}_{\text {Pump }}$ are the irreversibilities in the condenser, turbine and pump, respectively.

\section{RESULTS AND DISCUSSION}

The analysis was performed based on exergy, mass and energy balances and the following assumptions were taken into consideration for simulated ORC system:

- The organic Rankine cycle system runs as a steady process.

- The chemical exergy of the materials is not taken into consideration.

- The expander/turbine and the pumps in the modelled system are adiabatic devices.

- The working fluid which is 1, 1, 1, 3, 3pentafluroropropane (R-245fa) and at the pump inlet/condenser outlet is a saturated liquid.

- In any of the organic Rankine cycle devices, the pressure drop in the condenser and evaporator are neglected.

The model described in Figure 1 was used to simulate the behavior of the ORC system by varying the outlet temperature of the solar collector from $80{ }^{\circ} \mathrm{C}$ to $180{ }^{\circ} \mathrm{C}$ with a step size of $1{ }^{0} \mathrm{C}$ and hence variation in evaporator exit temperature in Table 4 shows the analysis of the results simulated at three consecutive evaporator exit temperatures using Aspen plus v8.0 simulator i.e. $129{ }^{\circ} \mathrm{C}, 130{ }^{\circ} \mathrm{C}$ and $131{ }^{\circ} \mathrm{C}$. The desired results were obtained at $130^{\circ} \mathrm{C}$ and the analysis was done based on collector temperature $163.5^{\circ} \mathrm{C}$ and evaporator exit temperature of $130{ }^{\circ} \mathrm{C}$.

Table 5 and Table 6 indicate the energy and exergy rates respectively for the $\mathrm{ORC}$ system, optimum temperature at the evaporator exit $\left(\mathrm{T}=130{ }^{\circ} \mathrm{C}\right)$

Figure 5 and Table 6 show the amount of exergy destruction in various components and based on the above presentation, it can be easily used in identifying the locations where there is minimum and maximum exergy destruction percentage. The analysis assists in highlighting the improvements in the system components and improving the overall energy efficiency of the ORC system. From the above analysis, the major source of exergy destruction is on the evaporator, which accounts for over $70 \%$ of the total exergy destroyed in the system followed by condenser, turbine and pump in the respective order. The largest exergy was destroyed in the evaporator due to the difference in temperature change between the incoming and leaving hot water in the component. It can be realized based on the calculations and simulated results that further improvement can be achieved through careful design of the evaporator and operation at optimum temperature. This improvement opportunity for evaporator can significantly improve the efficiency of the ORC system. The pump has negligible amount of exergy destruction from the simulated results in the ORC components and may not need to be improved. Based on the results, it can be highlighted that there is still room for performance improvement opportunities of the ORC system by improving each and every component's performance in the ORC.

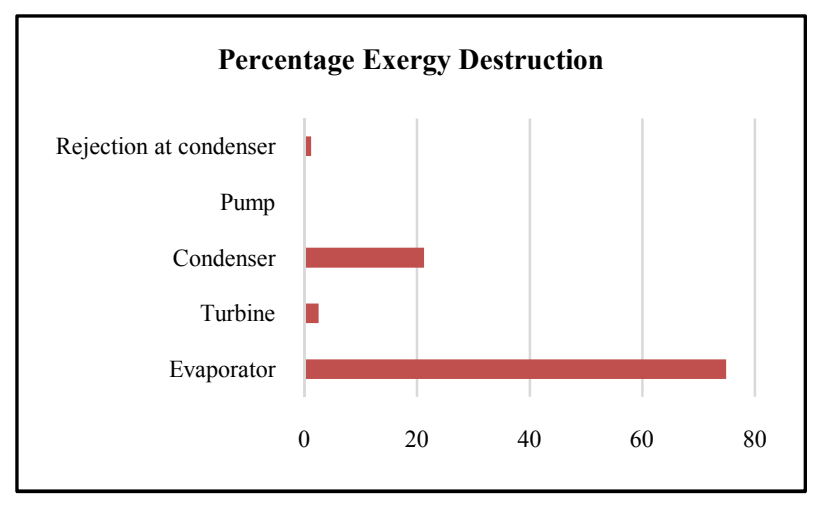

Figure 5 Percentage exergy of destruction in the ORC system components

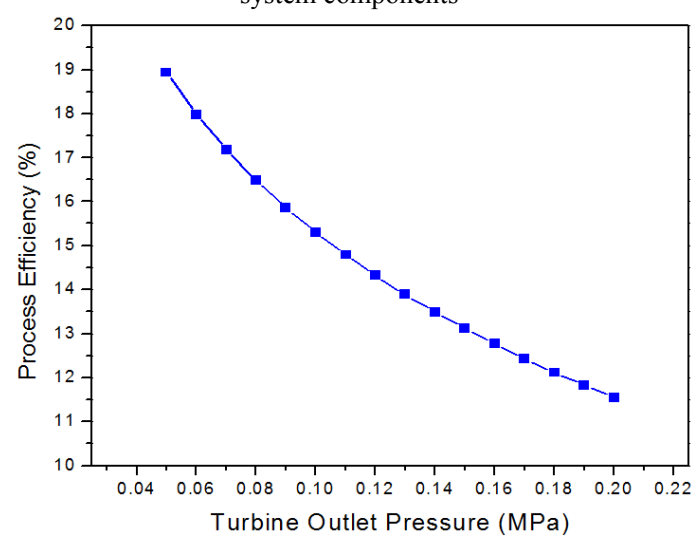

Figure 6 Variation of process efficiency with Turbine outlet pressure

In Figure 6, lowering the process efficiency tends to enhance turbine outlet pressure and vice versa. Thus the energy is 
decreased with increasing condenser pressure because there is a rise in the exergy destruction in the condenser.

Figure 7 shows the variation of the process efficiency when the condenser outlet temperature was varied.The process efficiency decreased with the increase of condenser outlet temperature, and this can be attributed to increase of outlet temperature in the turbine hence the heat exchange in the condenser increases. The condensing pressure in the ORC system has a distinct importance on the ORC system's performance since it assists in determining the overall heat rejection temperature, which is a crucial parameter for improving the efficiency in ORC apart from the heat input temperature. The condensing pressure varies inversely as the overall energy and exergy efficiency.

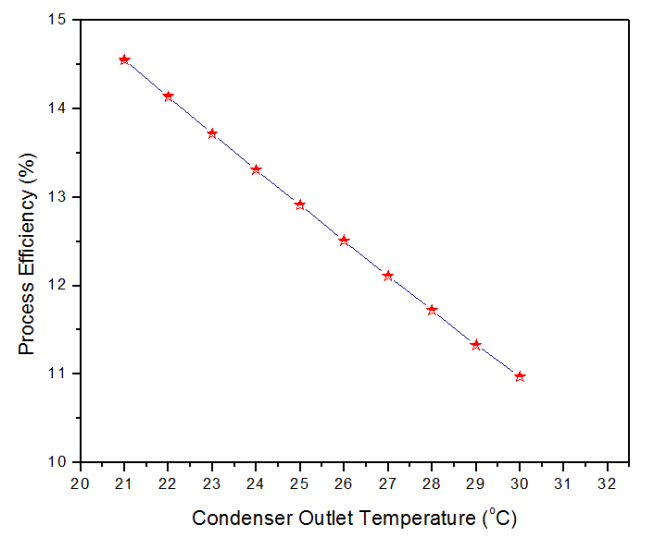

Figure 7 Variation of process efficiency with condenser outlet temperature

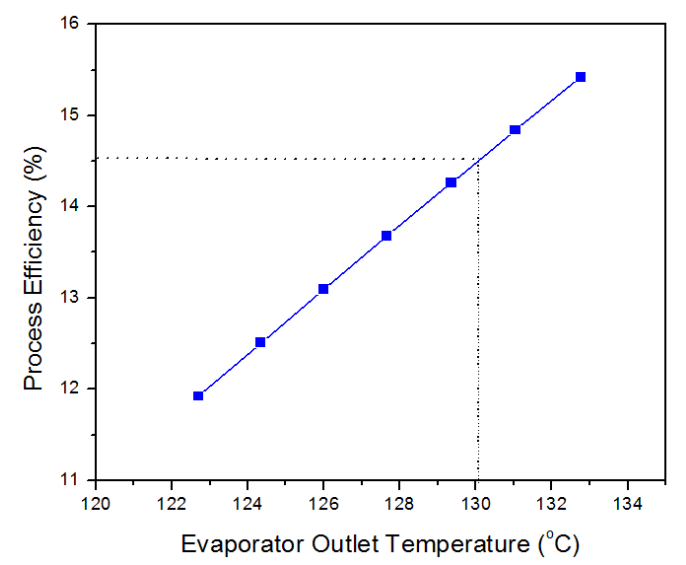

Figure 8 Variation of process efficiency with evaporator outlet temperature

The calculations of the working fluid mass flow rate, enthalpy, entropy and mole flow rate of the refrigerant R245fa, the corresponding, heat transmitting fluid (Therminol 55), hot water fluid and cooling water were calculated using Peng Robinson equation of state property set.

Figure 8 shows the variation of process efficiency with the outlet temperature in the evaporator. The process efficiency directly varies with evaporator outlet temperature. An overall efficiency is achieved at $14.55 \%$ at evaporator outlet temperature of $130{ }^{\circ} \mathrm{C}$.

\section{Validation of Results}

To validate the simulated model, various literatures and research work were carefully compared with the results achieved in this paper. The simulated data was validated by comparison with Quoilin et al. [35] work, under the same working fluid. The numerical results obtained show a very good agreement with the simulated data results in Table 7.

The ORC efficiency is $11.2 \%$, with $\mathrm{R} 245 \mathrm{fa}$ as the working fluid. The absolute difference is $13.5{ }^{0} \mathrm{C}$, with a relative difference of $9 \%$. The absolute difference in ORC efficiency is $3.35 \%$, whereas the relative difference in pinch point is $37.5 \%$. Moreover, the difference in collector's efficiency and the solar hours are almost the same, about $59 \%$ and 8 hours respectively. The possible difference in power output mainly arise from the pressure drop of the working fluid variation and differences in various component's specifications.

Table 7 Results validation

\begin{tabular}{cccc}
\hline Parameters & Ref. value[35] & Present value & Units \\
\hline $\mathrm{T}_{\text {evap }}$ & 150 & 163.5 & ${ }^{\circ} \mathrm{C}$ \\
$\mathrm{T}_{\text {amb }}$ & 15 & 25 & ${ }^{\circ} \mathrm{C}$ \\
$\eta_{O R C}$ & 11.2 & 14.55 & $\%$ \\
$\eta_{\text {Col }} \mathrm{T}_{0}$ & 61.6 & 59 & ${ }^{\circ} \mathrm{C}$ \\
$\quad \mathrm{P} . \mathrm{P}$ & 8 & 5 & ${ }^{\circ} \mathrm{C}$ \\
$n \quad$ & 8 & 8 & $\mathrm{hrs}$ \\
$\prod_{T, \text { max }}$ & 60 & 60 & \\
\multicolumn{1}{c}{$\mathrm{HTF}$} & Monoethylene & Therminol 55 & \\
\hline \multicolumn{5}{c}{ glycol } & &
\end{tabular}

BouLawz Ksayer [36] using 1,1,1,3,3-pentafluroropropane (R-245fa) as the working fluid evaluated a solar ORC for domestic hot water production and electricity generation. The process efficiency predicted was $14.5 \%$ during the peak solar hours, and with the same working fluid used in this paper, the results tally with the simulated data obtained using Aspen plus v8.0 from this paper with best performance efficiency at $14.55 \%$ achieved. Suresh et al. [18] using the small scale ORC system for rural areas electrical power generation application determined experimentally that the highest exergy of destruction occurred in the evaporator and in the pump there was negligible exergy of destruction occurrence.This is in line with the results achieved in this paper based on the simulated results and the calculations done using Peng Robinson equation of state.

\section{CONCLUSIONS}

In this paper, the exergetical performance of ORC solar system has been analyzed using Aspen plus v8.0 simulation software based on the second law of thermodynamics. The exergy of destruction is greatest in the evaporator component in the system. The following can be concluded from this study, increasing the turbine inlet temperature results in increasing the system net electric efficiency, net electric power, and exergy efficiency leads to improved exergetic and energetic system performance, which leads to decrease in exergy reduction rate. The exergy destruction reduction methods within the components in the ORC system are proposed to model the energy transfer process of the collector in the solar power plant, the proposed model allows the performance of the system for a wide range of working and ambient conditions. This analysis shows a beneficial energy guide for the simulations under the optimal working condition $\left(130^{\circ} \mathrm{C}\right)$ using solar as the source of energy simulations and subsequent calculations were carried out to research the heat transfer and exergy transfer performances along the ORC. The energy use efficiencies of the photovoltaic collector under different working conditions are revealed. The ORC 
system is an environmental-friendly technology, cost effective, simple to operate and it is suitable for Thika area given that the area experience a good solar conditions.

\section{Acknowledgments}

This work was financially supported by Chinese Scholarship Council (CSC) and the National Natural Science Foundation of China (Grant No. 51276055).

\section{References}

1. S. Lecompte, B. Ameel, D. Ziviani, M. Broek, M. Paepe. Exergy analysis of zeotropic mixtures as working fluids in Organic Rankine Cycles. Energy Conversion and Management 85(2014); 727-739.

2. Y. Zhu a, Z. Hub, Y. Zhou a, L. Jiang a, L. Yu. Applicability of entropy, entransy and exergy analyses to the optimization of the Organic Rankine Cycle. Energy Conversion and Management 88 (2014) 267276.

3. K. Darvish, M. Ehyaei, F. Atabi, M. Rosen. Selection of Optimum Working Fluid for Organic Rankine Cycles by Exergy and Exergy-Economic Analyses Sustainability 2015, 7, 15362-15383;

4. F. Hussain, M. Othman, K.Sopian, B.Yatim, H.Ruslan, H. Othman. Design development and performance evaluation of photovoltaic/thermal $(\mathrm{PV} / \mathrm{T})$ air base solar collector. Renewable and Sustainable Energy Reviews 25 (2013) 431-441.

5. F. Al-Sulaiman. Exergy analysis of parabolic trough solar collectors integrated with combined steam and organic Rankine cycles. Energy Conversion and Management 77 (2014) 441-449.

6. Derscha Jurgen, Geyer Michael, Herrmann Ulf, Jones Scott A, Kelly Bruce, Kistner Rainer, et al. Trough integration into power plants-a study on the performance and economy of integrated solar combined cycle systems. Energy 2004; 29:947-59.

7. Fredy Vélez, José J. Segovia, M. Carmen Martín, Gregorio Antolín, Farid Chejne, Ana Quijano. A technical, economical and market review of organic Rankine cycles for the conversion of low-grade heat for power generation. Renewable and Sustainable Energy Reviews 16 (2012) 4175- 4189

8. Fateme Ahmadi Boyaghchi, Hanieh Molaie. Advanced exergy and environmental analyses and multi objective optimization of a real combined cycle power plant with supplementary firing using evolutionary algorithm. Energy 93 (2015) 2267-2279.

9. A. Immanuel Selwynraj, S.Iniyan, L.Suganthi, M.Livshits, Guy Polonsky, Abraham Kribus. Annual Thermodynamic Analysis of Solar Power with Steam Injection Gas Turbine (STIG) Cycle for Indian Conditions. Energy Procedia 57 ( 2014 ) 2920 - 2929

10. Bertrand Fankam Tchanche, George Papadakis, Gregory Lambrinos, Antonios Frangoudakis. Fluid selection for a low-temperature solar organic Rankine cycle. Applied Thermal Engineering 29 (2009) 24682476.

11. M. Mujahid Rafique, P. Gandhidasan, Luai M. AlHadhrami, and Shafiqur Rehman. Energy, Exergy and Anergy Analysis of a Solar Desiccant Cooling System,
Journal of Clean Energy Technologies, Vol. 4, No. 1, January 2016

12. Christos Trivanidis, Evangelos Bellos, Kimon A. Antonopoulos. Energetic and financial investigation of a stand-alone solar-thermal Organic Rankine Cycle power plant. Energy conversion and Management 126 (2016) 421 - 433.

13. Masood Ebrahimi, Ali Keshavarz, Arash Jamali. Energy and exergy analyses of a micro-steam CCHP cycle for a residential building. Energy and Buildings 45 (2012) 202-210.

14. Ramon Ferreiro Garcia, Jose Carbia Carril, Javier Romero Gomez, Manuel Romero Gomez. Energy and entropy analysis of closed adiabatic expansion based trilateral cycles. Energy Conversion and Management 119 (2016) 49-59

15. Omer Kaynakli, Kenan Saka, Faruk Kaynakli. Energy and exergy analysis of a double effect absorption refrigeration system based on different heat sources. Energy Conversion and Management 106 (2015) 2130.

16. Yogev A, Kribus A, Epstein M. Solar tower reflector systems: a new approach solar plants. Int J Hydrogen Energy 1998; 23 (4):239-45.

17. Amine Kouta, Fahad Al-Sulaiman, Maimoon Atif, Saud Bin Marshad. Entropy, exergy, and cost analyses of solar driven cogeneration systems using supercritical $\mathrm{CO}_{2}$ Brayton cycles and MEE-TVC desalination system Energy Conversion and Management 115 (2016) 253-264.

18. Suresh Baral, Dokyun Kim, Eunkoo Yun, Kyung Chun Kim. Energy, Exergy and Performance Analysis of Small-Scale Organic Rankine Cycle Systems for Electrical Power Generation Applicable in Rural Areas of Developing Countries. Energies 2015, 8, 684-713;

19. Stefano Bracco, Silvia Siri. Exergetic optimization of single level combined gas-steam power plants considering different objective functions. Energy 35 (2010).

20. Abdolsaeid Ganjeh Kaviri, Mohammad Nazri Mohd. Jaafar, Tholudin Mat Lazim, Hassan Barzegaravval. Exergoenvironmental optimization of Heat Recovery Steam Generators in combined cycle power plant through energy and exergy analysis. Energy Conversion and Management 67 (2013) 27-33.

21. Amin Mohammadi Khoshkar Vandani, Mokhtar Bidi, Fatemeh Ahmadi. Exergy analysis and evolutionary optimization of boiler blowdown heat recovery in steam power plants. Energy Conversion and Management 106 (2015) 1-9.

22. Suresh Baral, Dokyun Kim, Eunkoo Yun, Kyung Chun Kim. Experimental and Thermoeconomic Analysis of a small-Scale Solar Organic Rankine Cycle. Entropy 2015,17,2039-2061;

23. Lalatendu Pattanayak, Jaya Narayan Sahu. Steady state modeling on energy and exergy analysis of a pulverized coal fired thermal power plant. Asia-Pac. J. Chem. Eng. 2015; 10: 876-884.

24. M. Khaljani, R. Khoshbakhti Saray, K. Bahlouli. Thermodynamic and thermoeconomic optimization of an integrated gas turbine and organic Rankine cycle. Energy 93 (2015). 
25. Esa Dube Kerme, Jamel Orfi. exergy- based thermodynamic analysis of solar driven Organic Rankine Cycle- Research Article - JTEN - 2014 - 33.

26. J.K Kiplagat, R.Z Wang, T.X Li. Renewable energy in Kenya; Resource potential and status of exploration. Renewable and sustainable energy reviews 15 (2011) 2960-2973.

27. Cheng Eng Cong, Sanjayan Velautham, Amer Nordin Darus. Solar thermal Organic Rankine Cycle as a renewable energy option. Jurnal Mekanikal December 2005, No. 20, 68 - 77.

28. Duffie, J.A. and Beckman, W.A., (1991), Solar Engineering of Thermal Processes. 2nd Ed. U.S.A.: John Wiley and Sons, Ltd.

29. Pei Gang, Li Jing, Ji Jig. Analysis of low temperature solar thermal electric generation using regenerative Organic Rankine Cycle. Applied Thermal Engineering 30 (2010) 998-1004.

30. Agustín M. Delgado-Torres, Lourdes GarcíaRodríguez. Analysis and optimization of the lowtemperature solar organic Rankine cycle (ORC). Energy Conversion and Management 51 (2010) 28462856.

31. Francis Oloo, Luke Olang, Josef Strobl. Spatial modelling of solar energy potential in Kenya. International Journal of sustainable energy planning and management. Vol.06 2016 17-30.
32. Herena Tor1o, Adriana Angelotti, Dietrich Schmidt. Exergy analysis of renewable energy-based climatisation systems for buildings: A critical view. Energy and Buildings 41 (2009) 248-271.

33. Joan Carles Bruno, Jesu's Lo'pez-Villada, Eduardo Letelier, Silvia Romera, Alberto Coronas. Modelling and optimisation of solar organic rankine cycle engines for reverse osmosis desalination. Applied Thermal Engineering 28 (2008) 2212-2226.

34. Sylvain Quoilin, MartijnVanDenBroek, Se' bastien Declaye, PierreDewallef, VincentLemort. Technoeconomic survey of Organic Rankine Cycle (ORC) systems. Renewable and Sustainable Energy Reviews 22 (2013) 168-186.

35. Quoilin, S.; Orosz, M.; Hemond, H.; Lemort, V. Performance and design optimization of a low-cost solar organic Rankine cycle for remote power generation. Sol. Energy 2011, 85, 955-966.

36. Ksayer, E. Design of an ORC system operating with solar heat and producing sanitary hot water. Energy Proced. 2011, 6, 389-395.

\section{How to cite this article:}

Adwek Odhiambo George et al (2017) ' Energy, Anergy And Exergy Analysis Of Organic Rankine Cycle For A Residential Apartment Using Solar Energy Based On Aspen Plus', International Journal of Current Advanced Research, 06(04), pp. 3545-3554. DOI: http://dx.doi.org/10.24327/ijcar.2017.3554.0312 